it is naturally an embodiment of his views, and, although we notice with satisfaction that it has been very carefully rewritten, the subject matter is essentially the same. The most notable part is the paragraph on stricture of the urethra. The results obtained by Mr. Bruce Clarke and the authors entitle them to believe themselves exceptionally fortunate-and there will be found those who regard the operation as involving elements of danger and uncertainty. At the same time, it must be admitted that the account given here is based upon the very highest authority.

Names and therr Meanings: A Book for the Curious.

By Lropold Wagner. New Edition. London: Fisher Unwin, 1892.

Since the medical philologist is only expected to cultivate one small corner of the field of the science of language, he feels some natural diffidence in criticising a book which only deals with his special region in an incidental manner.

Perhaps, however, he may not be considered presumptuous in suggesting that the derivation of such words as " humbug" and "dun" from those imaginary persons, "Mr. Hume of the Bogue " and "Mr. Joe Dun, famous bailiff of Lincoln," savours of antediluvian methods, and is nearly as scientific a specimen of philology, as our author's ascription of a skeleton found near Battle Bridge to an elephant slain by Queen Boadicea, is of his historical acumen. We might hint also that Woodfall is not "the reputed author of 'Junius;" that Robert Fitzooth is hardly satisfactorily established as a veritable Norman nobleman, much less as the real Robin Hood ; that Charles II. did not return to England on " his birthday, May 29th, 1651;" that Guy Fawkes was not " the principal conspirator in the Gunpowder Plot;" and that Quentin Matsy's "masterpiece of world-wide renown" is not the "Taking down from the Cross" (can Mr. Wagner be thinking of Rubens's painting in Antwerp Cathedral ?). Nor were the Duke of Marlborough and Napoleon I. called respectively "Corporal" by their soldiery, because they had risen from corporals. Was the founder of St. Bartholomew's Hospital "Rahare, a monk ?" To return to our own province. Were the barbers and surgeons separated in 1540? The derivation of "quack" from the German word for quicksilver cannot be maintained."

Our author unhesitatingly settles the origin of the gipsies in Hindustan, and give the exact date of their expulsion without any reserve, an accuracy of knowledge which even the best authorities have not elsewhere attained to. His derivation of "bachelor" from the Welsh bach, small, little, is purely dogmatic, although Skeat says there is no evidence for it. He seems to confuse cognate forms with original derivations, as when he derives "widow" from the Sanskrit vidhava, "without husband." Widow is derived from the Saxon widwe, a widow: this is akin to the Sanskrit vidhava, a widow, both being probably derived from the same original root widh, but the Anglo-Saxon is no more derived from the Sanskrit than the Sanskrit from it; they are cognate form, that is all; and, by the way, vidhava, a widow, is not held by the best authorities to be the same as $v i$ without, dhava, a husband, as given in this work.

The very faults of the book make it attractive as a popular guide. The general reader does not value or look for accuracy; he is apt to prefer definite undoubting information even when fallacious, and if it is amusing so much the better.

Human Monstrositims. By Barton Cooke Hirst, M.D., Professor of Obstetrics, and George A. Piersol, M.D., Professor of Histology and Embryology in the University of Pennsylvania. Part III. Illustrated with Nine Photographic Reproductions and Thirty-four Woodcuts. Philadelphia: Lea Brothers and Co. 1892.

THE first volume of Human Monstrosities was reviewed in the British Mrdical Journal for January 9th, 1892, p. 73, where the plan of the work was explained. Like the second part, this is superior to the first, as it is not overburdened with introductory matter. It includes cyclops and otocephalus and

1 Vide Skeat's Dictionary, 8. v. Quack. agnathia, which conclude the series of single monsters, the very important group of omphalosites or acardiacs, and the diprosopus and allied varieties of composite monsters.

The acardiacs are especially important in relation not only to embryology, but also to the question of placental circulation. The authors reject the more common name " acardiac" chiefly on the score that many acardiacs possess rudimentary hearts. This is not a perfectly scientific reason for rejecting. the term; zoologists have not abolished the name marsupialio. because some marsupials have no marsupium. They are; however, right in many respects in retaining the older term: omphalosite; it cannot mislead, and it was introduced by a great authority. Drs. HIRst and PIERsol most commendably take pains to explain thoroughly the current theory concerning the development of acardiac twins. Claudius and Ahlfeld maintained that the autosite's allantois developing first. reaches the inner surface of the primary chorion which it. monopolises, so that the allantois of the parasite cannot reach the chorion, but becomes inserted into the other allantois. Hence vascular anastomosis is established, and the parasite receives blood from the autosite, the current in its body being reversed. The heart fails to develop, and entire parts of the body are suppressed from want of arterial blood. This suppression is totally unlike atrophy or destruction by inflammatory processes. This plausible theory is doubtless substantially correct; insertion of a twin's umbilical cord in its brother's cord is usually accompanied by more or less imperfect development of the former twin. Breus, however, disputes the precise reversal of blood-current doctrine, and believes that the parasite has suffered in some early stage from internal disturbance of development, and when thus deprived of an independent circulation the blood currents of the autosite enter the vessels of the omphalosite or parasite, and keep it nourished to an imperfect degree. The authors of Human Monstrosities give the opposite opinions of Ahlfeld and Breus at length. Altogether this volume is the best of the three which have already appeared.

ERRATUM. - In the review of Dr. Edwardes's book on Vaccination and Small-pox in the BRITISH MedicAL JoURNAL of November 26th, page 1175 col. 1 , line 5 , the flgures should read 2,6 , and 42 .

\section{REPORTS AND ANALYSES}

\section{DESCRIPTIONS OF NEW INVENTIONS IX MEDICINE, BURGREY, DIETETICS, $\triangle N D$ THB ATLIRD BCIRNCEA.}

\section{LIQUOR POTASS}

THIs preparation is a solution of iodide and hypiodite of potassium. It is a colourless and rather alkaline liquid, from which the iodine is immediately liberated by the addition of dilute hydrochloric acid. It is the opinion of some therapeutists that free iodine internally is more effectual than the alkaline iodides. This solution is a very convenient and pleasant way of administering iodine, for there can be no doubt that the iodine is at once set free by the acid of the stomach, and is thus in a favourable condition for local action or rapid absorption. The manufacturers of liquor potassæ iodinatæ are Messrs. Willows, Francis, and Butler, wholesale druggists, 101, High Holborn, London, W.C.

\section{URETHRAL INJECTORS.}

DR. JAMES MACMONN (Crouch End) writes : In connection with the subject of a urethral injector, described in the BRITISH MEDICAL JOURNAL of November 12th, for years I have used a contrivance of the same kind and with the same stated objects in view. The instrument (vulcanite) is bent so as to reach the prostatic urethra if desired. It consists of a long stem, terminating in a conical end an inch in length, this conical end being 23 millimetres at the base, and 12 millimetres at the point and perforated with holes countersunk. The stem is graduated. Thus it will be seen that it will fulfil all the indications met by the suggestion of Mr. Burton ; and possesses, perhaps, one advantage-namely, that bent more or straightened. 